\title{
Anti-Methicillin Resistant Staphylococcus aureus Activity and Optimal Culture Condition of Streptomyces sp. SUK 25
}

\author{
Ahmad Siti Junaidah ${ }^{1}$; Sudi Suhaini ${ }^{2}$; Hasidah Mohd Sidek ${ }^{2}$; Dayang Fredalina Basri ${ }^{1}$; \\ Noraziah Mohamad Zin ${ }^{3, *}$ \\ ${ }_{1}^{1}$ School of Diagnostic and Biomedical Sciences, Faculty of Medicine and Health Sciences, University Sultan Zainal Abidin, Kuala Terengganu, Terengganu, Malaysia \\ ${ }_{3}^{2}$ School of Bioscience and Biotechnology Study, Faculty of Science and Technology, University Kebangsaan Malaysia, Selangor, Malaysia \\ ${ }^{3}$ School of Diagnostic and Applied Health Sciences, Faculty of Health Sciences, University Kebangsaan Malaysia, Kuala Lumpur, Malaysia \\ ${ }^{*}$ Corresponding author: Mohamad Zin Noraziah, School of Diagnostic and Applied Health Sciences, Faculty of Health Sciences, University Kebangsaan Malaysia, Kuala Lumpur, \\ Malaysia. Tel:+60-392897373, E-mail: noraziah.zin@ukm.edu.my
}

Received: December 21, 2013; Revised: March 25, 2014; Accepted: May 6, 2014

\begin{abstract}
Background: The potential of secondary metabolites extracted from Streptomyces sp. to treat bacterial infections including infections with Staphylococcus aureus is previously documented. The current study showed significant antimicrobial activities associated with endophytic Streptomyces sp. isolated from medicinal plants in Peninsular Malaysia.

Objectives: The current study aimed to determine anti-methicillin-resistant-Staphylococcus aureus (MRSA) activities of Streptomyces sp. isolates.

Materials and Methods: Disc diffusion and Minimum Inhibitory Concentration (MIC) assay were used to determine the antibacterial activity of Streptomyces sp. isolates. Optimization of fermentation parameters for the most potent anti-MRSA extract in terms of medium type, $\mathrm{pH}$, aeration rate, and culture period was also carried out. Lastly, toxicity of the extract against Chang liver cells was determined employing the MTT, 2-(3, 5- diphenyltetrazol-2-ium-2-yl)-4,5-dimethyl-1,3-thiazole; bromide assay.

Results: The results indicated Streptomyces sp. SUK 25 isolates showed the most potent anti-MRSA activity. Disc diffusion assay revealed that spread plate technique was more efficient in screening anti-MRSA activity compared to pour plate $(\mathrm{P}<0.05)$. To determine anti-MRSA MIC of Streptomyces sp. SUK25, Thronton media was used. Therefore, MIC was determined as $2.44 \pm 0.01 \mu \mathrm{g} / \mathrm{mL}$, and accordingly, the lowest MIC was $1.95 \mu \mathrm{g} / \mathrm{mL}$ based on a seven-day culture, $\mathrm{pH}$, and aeration rate of $140 \mathrm{rpm}$. The crude extract was not toxic against Chang liver cells $\left(\mathrm{IC}_{50}=43.31 \pm 1.24 \mu \mathrm{g} / \mathrm{mL}\right)$.

Conclusions: The Streptomyces sp. SUK 25 culturing was optimized using Thronton media, at pH 7 and aeration of 140 rpm. Further isolation and identification of bioactive compounds will develop anti-MRSA therapeutics.
\end{abstract}

Keywords: Streptomyces sp.; MRSA; Culture

\section{Background}

Endophyte bacteria is an organism that lives in plant tissues, and acts as symbiont with the host and secreted beneficial products (1). Examples of metabolites with medicinal value were taxol, cryptocin, and cryptocandin (2). The study by Zin et al. (3) showed that the secondary metabolites of endophytic Streptomyces possessed characteristics similar to anti-fungal agent. These secondary metabolites were extensively studied and the obtained antibiotic compounds were reported by researchers and pharmaceutical agencies $(4,5)$. Finding alternatives for MRSA treatments need to be initiated. It is reported that Metabolites obtained from Streptomyces sp. act as antibacterial agents against pathogenic bacteria. Authors' previous work indicated that endophytic Streptomyces sp isolated from medicinal plants in Malay Peninsula had significant antimicrobial activities (6).

\section{Objectives}

The current study aimed to determine the most potent Streptomyces sp. isolates, SUK 25, as anti-MRSA agent and evaluate its optimal culture conditions as well as the cytotoxic effect.

\section{Materials and Methods}

\subsection{Test Microorganism}

The sample of entophytic actinobacteria, SUK (Strain of University Kebangsaan Malaysia), and MRSA were obtained from the Novel Antibiotic laboratory in UKM, Kuala Lumpur. The SUK collection namely SUK 25, SUK 27, SUK 28, and SUK 30, and MRSA culture were MRSA ATCC 33591, MRSA ATCC 43300 and MRSA 49476. These endophytic Streptomyces sp. were previously isolated from medicinal plants in Malay Peninsula (7). The SUK

Copyright (C) 2015, Ahvaz Jundishapur University of Medical Sciences. This is an open-access article distributed under the terms of the Creative Commons Attribution-NonCommercial 4.0 International License (http://creativecommons.org/licenses/by-nc/4.0/) which permits copy and redistribute the material just in noncommercial usages, provided the original work is properly cited. 
25 and SUK 27 were isolated from Zingiber spectabile, while SUK 28 and SUK 30 were isolated from Sarcandra glabra and Oroxylum indicum, respectively (8). The 14day culture was on ISP 2 (International Streptomycetes Project 2) agar at $28^{\circ} \mathrm{C}$ and maintained at $-80^{\circ} \mathrm{C}$ in $20 \%$ glycerol (Merck, USA) solution (9), while MRSA strain was maintained on Mueller Hinton Agar (Merck, USA) (MHA) supplement with $2 \%$ Sodium Chloride, $\mathrm{NaCl}$ (Sigma Aldrich, USA) at $8^{\circ} \mathrm{C}$.

\subsection{Anti-Bacterial Screening}

Bioassays of 4 isolates of Actinobacteria from various sources of medicinal plants (SUK 25, SUK 27,SUK 28, and SUK 30) were screened against MRSA ATCC strains of 33591, 43300, and 49476 (7). One cubic centimeter (1 $\mathrm{cm}^{3}$ ) of matured actinobacteria was placed on nutrient agar (Merck, USA) lawn with MRSA. The inhibition zone was measured after overnight incubation in which Vancomycin (30 $\mu \mathrm{g} /$ disc) (Oxoid, UK) was used as positive control. These 4 isolates were then preceded for fermentation in nutrient broth followed by extraction and tested against MRSA through disc assay method. Known amounts of extract (in methanol) were placed on blank disc ( 6 mm diameter, Whatman ${ }^{\mathrm{TM}}$, Gred AA) (Sigma Aldrich, USA), then dried in the hood. After that, the disc was placed on the MHA already lawn with MRSA. This culture was incubated overnight at $37^{\circ} \mathrm{C}$. After overnight culture, the inhibition zone was measured for each plate and Vancomycin (30 $\mu \mathrm{g} /$ disc) (Oxoid, UK) was used as a positive control. Culturing techniques, spread plate method (SPM) and pour plate method (PPM), were used according to the standard method (10) for the selected SUK (based on anti-MRSA properties), which was SUK 25. These steps meant to determine the capability of extracts exploited from SUK 25 to penetrate the target MRSA cells efficiently.

\subsection{Cultural Condition of SUK Isolates}

Culture conditions for the production of anti- MRSA was determined by inoculation of 5-6 cubic centimeter $\left(\sim 1 \mathrm{~cm}^{3}\right)$ of matured SUK 25 from ISP 2 media into one-third of $1 \mathrm{~L}$ Erlenmeyer flasks (Pyrex, USA) each containing a sterilized $400 \mathrm{~mL}$ broth. The flasks were incubated for 7 days at $28^{\circ} \mathrm{C}$ with aeration rate of 160 rpm. Eight fermentation medium with modified formula were used, namely $\mathrm{A}_{3}$ M Media (11), Bn-2 Media (11), ISP 9 Media (12), Czapek-Dox Media (13), Bennette Media (6), Thronton's Media (14), Heydorn Media (15) and Nutrient Broth (Merck, USA). After that, the selected media was optimized based on its anti-MRSA activities, whereby the involved parameters were incubation period, $\mathrm{pH}$ level of the media and aeration rate.

\subsection{Ethyl Acetate Extraction}

Ethyl acetate extraction (3) was employed to harvest the secondary metabolite from the fermented broth af- ter 7 days of incubation. Culture filtrates were extracted with three half-volume of ethyl acetate. After that, solvent phase was concentrated with rotary evaporator (Buchi, Switzerland) at $40^{\circ} \mathrm{C}$ and was left to dry. The obtained crude extracts were suspended in methanol (Sigma Aldrich, USA) and used for MIC determination assay against MRSA (10). The SUK 25 extracts exploited from different media (namely, $\mathrm{A}_{3} \mathrm{M}$ Media, Bn-2 Media, ISP 9 Media Czapek-Dox Media, Bennette Media Thronton's Media, Arney Heydorn Media and Nutrient Broth) were preceded for MIC determination. The concentration used in this study was $0.488 \mu \mathrm{g} / \mathrm{mL}-1000 \mu \mathrm{g} / \mathrm{mL}$.

\subsection{Cytotoxicity Test}

Cytotoxicity effect of SUK 25 extracts were tested against mammalian Chang liver cells, following a method described by Babu et al. (16). This experiment was carried out to determine hepatocellular viability of the cells after post treatment with SUK 25 extracts. Therefore, the obtained results reflect the human hepatocellular toxicity level. Chang liver cells were grown in complete Dulbecco's Modified Eagle Medium (DMEM) (GIBCO, NY) supplemented with 10\% fetal bovine serum and $1 \%$ penicillin/streptomycin, seeded to 96 -well plates at $5 \times 10^{4}$ cells/well and incubated at $37^{\circ} \mathrm{C}$, and $5 \% \mathrm{CO}_{2}$ for 48 hours. After incubation, the culture medium was replaced with $100 \mu \mathrm{L}$ of SUK 25 extracts at concentrations ranging from $0.001-1000 \mu \mathrm{g} / \mathrm{mL}$ diluted serially using DMEM. Incubation was carried out for another 48 hours. Cells incubated in $100 \mu \mathrm{L}$ DMEM without extracts were used as controls. Following the incubation with extracts, $5 \mathrm{mg} / \mathrm{mL}$ of 3- (4,5 - dimethylthiazol - 2 - yl) - 2, 5 - diphenyl tetrazolium bromide (MTT) (Sigma-Aldrich Co., USA) solution in phosphate buffered saline (PBS) was added to each well and incubated further for 3-4 hours. The medium was then carefully replaced with $100 \mu \mathrm{L}$ dimethyl sulfoxide (DMSO) and mixed thoroughly to dissolve the formazan crystal product. Absorbance was then measured at $540 \mathrm{~nm}$ using a microtiter plate reader (SLT-Labinstruments, Germany). Cell viability was calculated using the following formula:

\% Cell viability:

(Mean absorbance in the test wells)/(Mean absorbance in the control wells) $\times 100$

The $\mathrm{IC}_{50}$ values were obtained from a dose-response curve for each tested extract.

\subsection{Statistical Analysis}

The obtained data were assessed using IBM SPSS version 21. The ANOVA (Analysis of Variance) was employed and the level of significance was $\mathrm{P}<0.05$. Post-hoc test (Post Turkey test) investigated the differences between data $(\mathrm{P}<0.05)$.

\section{Results}

As documented in Figure 1 (ii), the crude extracts of 
Siti Junaidah A et al.

4 isolates namely SUK 25, SUK 27, SUK 28 and SUK 30 were used to screen anti-MRSA metabolites. These four isolates were screened to determine their capability in producing secondary metabolites. At this stage, the SUK 25 isolate was found a potential anti-MRSA agent. The inhibition zones of MRSA ATCC 49476, MRSA ATCC 43300, and MRSA ATCC 33591 were $30 \mathrm{~mm}, 20 \mathrm{~mm}$ and $21 \mathrm{~mm}$ respectively when reacting against SUK 25 extracts compared to Vancomycin with inhibition zones of $16 \mathrm{~mm}, 15 \mathrm{~mm}$ dan $15 \mathrm{~mm}$, respectively. In addition, the one-way ANOVA indicated that data for the inhibition zone of MRSA ATCC 43300 produced by SUK 25 extracts were significantly different, using pour plate and spread plate techniques $(\mathrm{P}<0.05)$.

The spread plate method (SPM) exhibited a significantly higher inhibition zone value against MRSA ATCC 43300 compared to pour plate method (PPM) at $19 \pm$ $0.26 \mathrm{~mm}$ and $15 \pm 0.38 \mathrm{~mm}$, respectively by Post Turkey HSD test. SPM was selected to screen the secondary metabolite against MRSA, since this technique produced a significantly bigger inhibition zone than PPM $(\mathrm{P}<$ 0.05), Figure 1 (i). Parameters used to determine the optimal culture condition for the best anti-MRSA activities of SUK 25 included type of media, fermentation period, $\mathrm{pH}$ media, and aeration rate for optimal oxygen sources. According to Figure 2, eight media namely $\mathrm{A}_{3} \mathrm{M}$, ISP 9, Bennette, Nutrient Broth, Arney Hedron's, Bn-2, Thronton's and Czapek-Dox were screened to en- rich the secondary metabolite production of SUK 25. The activity can be assessed by measuring its capability to produce the lowest MIC value to inhibit MRSA ATCC 43300 as well as high weightage of the dry weight of the crude extracts produced by SUK 25 with constant volume of $400 \mathrm{~mL}$, initial $\mathrm{pH} \mathrm{7}$, and an incubation period of 7 days. Growth curve of SUK 25 (Figure 3) in the Thronton medium was measured using Absorbance reading at $625 \mathrm{~nm}\left(\mathrm{~A}_{625}\right)$.

The result showed that the bacteria enter the stationary phase on the 7th day. Therefore, the secondary metabolites were harvested after 7 days of culture growth. Figure 4 shows that the lowest MIC value $(2.44 \pm 0.01 \mu \mathrm{g} /$ $\mathrm{mLg} / \mathrm{mL}$ ) was through incubating the SUK 25 in Thronton's media followed by Czapek-Dox with $5.86 \pm 0.01 \mu \mathrm{g} /$ $\mathrm{mLg} / \mathrm{mL}$, Arney Hedron's with $6.25 \pm 0.1 \mu \mathrm{g} / \mathrm{mLg} / \mathrm{mL}$, Nutrient Broth and ISP 9 with $1000 \mu \mathrm{g} / \mathrm{mLg} / \mathrm{mL}$, Bennette and Bn-2 with $8000 \mu \mathrm{g} / \mathrm{mLg} / \mathrm{mL}$, and $\mathrm{A}_{3} \mathrm{M}$ media with $32000 \mu \mathrm{g} / \mathrm{mL}$. While the trends in producing weightage of the crude extracts exploited from the $400 \mathrm{~mL}$ media was led by $\mathrm{A}_{3} \mathrm{M}$, then Bn-2, ISP 9, Arney Hedron's, Bennette, Nutrient Broth, Czapek-Dox and Thronton's with crude extract weightage $104 \pm 0.1 \mathrm{mg}, 7 \pm 0.2 \mathrm{mg} 5.8 \pm 0.1$ $\mathrm{mg}, 2.8 \pm 0.2 \mathrm{mg}, 2.4 \pm 0.2 \mathrm{mg}, 2.3 \pm 0.1 \mathrm{mg}, 0.9 \pm 0.1 \mathrm{mg}$ and $0.5 \pm 0.1 \mathrm{mg}$, respectively. However, it was noteworthy that despite the high weightage value of the crude extract $\mathrm{A}_{3} \mathrm{M},(104 \pm 0.1 \mathrm{mg})$, its antibacterial effect was the lowest, $(32000 \mu \mathrm{g} / \mathrm{mL})$.

Table 1. Comparison of Sources of Each Fermentation Media, Minimum Inhibitory Concentration Value, and Weight of Crude Extracts Produced by Media Fermentation ${ }^{\text {a }}$

\begin{tabular}{|c|c|c|c|c|c|c|c|c|}
\hline Media & Thronton's & Czapek-Dox & $\begin{array}{l}\text { Arney Hey- } \\
\text { dron }\end{array}$ & Nutrien & ISP 9 & Bennette & Bn-2 & $\mathbf{A}_{3} \mathbf{M}$ \\
\hline $\begin{array}{l}\text { Carbon } \\
\text { Sources }\end{array}$ & Mannitol & Sucrose & Glucose & None & Glucose & Glucarose & $\begin{array}{c}\text { Glucose, } \\
\text { soluble starch }\end{array}$ & $\begin{array}{l}\text { Glucose, } \\
\text { Soluble starch, } \\
\text { glycerol, } \\
\text { reducing sugar, } \\
\text { nonreducing } \\
\text { sugar, fat and } \\
\text { carbohydrate } \\
\text { from Pharma- } \\
\text { media SDN } \\
\text { BHD. }\end{array}$ \\
\hline
\end{tabular}

\begin{tabular}{|c|c|c|c|c|c|c|c|c|}
\hline $\begin{array}{l}\text { Nitrogen } \\
\text { Sources }\end{array}$ & $\begin{array}{l}\text { Potassium } \\
\text { Nitrate, As- } \\
\text { paragine }\end{array}$ & $\begin{array}{l}\text { Sodium } \\
\text { Nitrate }\end{array}$ & $\begin{array}{l}\text { Ammonium } \\
\text { Chloride, Am- } \\
\text { monium Iron } \\
\text { (III) Citrate }\end{array}$ & $\begin{array}{l}\text { from } \\
\text { racts }\end{array}$ & $\begin{array}{l}\text { Ammonium } \\
\text { sulfate }\end{array}$ & $\begin{array}{l}\text { Yeast extracts, } \\
\text { meat extracts } \\
\text { and } N-Z \text { case }\end{array}$ & $\begin{array}{c}\text { Yeast extracts, } \\
\text { meat extracts } \\
\text { and N-Z case }\end{array}$ & $\begin{array}{c}\text { Total protein, } \\
\text { Amino soluble } \\
\text { nitrogen, Acid } \\
\text { amino (Phar- } \\
\text { mamedia SDN } \\
\text { BHD) }\end{array}$ \\
\hline $\begin{array}{l}\text { MIC } \\
\text { value and } \\
\text { weight } \\
\text { of crude } \\
\text { extracts } \\
\text { produced }\end{array}$ & $\begin{array}{c}\text { MIC value: } \\
2.44 \mu \mathrm{\mu g} / \mathrm{mL} ; \\
\text { Weight of } \\
\text { crude extracts } \\
\text { produced: } 0.5 \\
\text { mg/400 mL }\end{array}$ & $\begin{array}{l}\text { MIC value: } \\
5.86 \mu \mathrm{g} / \mathrm{mL} ; \\
\text { Weight of } \\
\text { crude extracts } \\
\text { produced: } 0.9 \\
\text { mg/400 mL }\end{array}$ & $\begin{array}{l}\text { MIC value: } \\
6.25 \mu \mathrm{g} / \mathrm{mL} \text {; } \\
\text { Weight of } \\
\text { crude extracts } \\
\text { produced: } 2.8 \\
\text { mg/400 mL }\end{array}$ & $\begin{array}{l}\text { MIC value: } \\
1000 \mu \mathrm{g} / \mathrm{mL} ; \\
\text { Weight of } \\
\text { crude extracts } \\
\text { produced: } 2.4 \\
\text { mg/400 mL }\end{array}$ & $\begin{array}{l}\text { MIC value: } \\
1000 \mu \mathrm{g} / \mathrm{mL} ; \\
\text { Weight of } \\
\text { crude extracts } \\
\text { produced: } 5.8 \\
\text { mg/400 mL }\end{array}$ & $\begin{array}{l}\text { MIC value: } \\
8000 \mu \mathrm{g} / \mathrm{mL} ; \\
\text { Weight of } \\
\text { crude extracts } \\
\text { produced: } 2.3 \\
\text { mg/400 mL }\end{array}$ & $\begin{array}{c}\text { MIC value: } \\
8000 \mu \mathrm{g} / \mathrm{mL} ; \\
\text { Weight of } \\
\text { crude extracts } \\
\text { produced: } 7.0 \\
\text { mg/ mL }\end{array}$ & $\begin{array}{l}\text { MIC value: } \\
32000 \mu \mathrm{g} / \\
\text { mL; Weight of } \\
\text { crude extracts } \\
\text { produced: } 104.0 \\
\text { mg/400 mL }\end{array}$ \\
\hline
\end{tabular}

\footnotetext{
${ }^{a}$ Abbreviations: MIC, minimum inhibitory concentration; ISP, International Streptomyces Project; Bn-2, Bennette media; $\mathrm{A}_{3} \mathrm{M}, \mathrm{A}_{3} \mathrm{M}$ media; SDN BHD, Private limited.
} 
Independent t-test revealed that the MIC value of Thronton's media $(2.44 \pm 0.01 \mu \mathrm{g} / \mathrm{mLg} / \mathrm{mL})$ was significantly different compared with that of Czapek-Dox $(5.86 \pm 0.01 \mu \mathrm{g} / \mathrm{mL}), \mathrm{P}<0.05$. Therefore, Thronton medium was selected as the best media to produce antiMRSA metabolites (Figure 4). This media contains only one carbon source mannitol and two nitrogen sources namely potassium nitrate and asparagines. These results showed that the production of crude extracts was inversely proportional to the production of active extracts with potential secondary metabolite. Table 1 presented the comparison between the sources of each media used, their MIC values and the weight of crude extracts produced by the media fermentation. As shown in Figure 4, incubation period, the initial $\mathrm{pH}$ medium and aeration rate were optimized in Thronton's media.

The anti-MRSA activity and weightage of SUK 25 crude extract was assessed on the 3rd, 7th, 14th and 21st days of fermentation. As indicated in Figure 4 (i), the 7- day fermentation period produced $(\mathrm{P}<0.05)$ the highest activity (lowest MIC value, $2.44 \pm 0.01 \mu \mathrm{g} / \mathrm{mL} \mu \mathrm{g} / \mathrm{mL}$ ) compared to the other periods of fermentation ( $\mathrm{P}<$ $0.05)$. The crude extract produced the highest weightage on the 21st day with $1.2 \pm 0.01 \mathrm{mg}$, $(\mathrm{P}<0.05)$ compared to the other fermentation days of interval except the 14th day fermentation $(P>0.05)$. Since the antibacterial effect was selected as the primary criteria, optimum fermentation period was the 7th day of fermentation period (Figure 4). The initial $\mathrm{pH}$ of Thronton media was determined through 5 interval values, starting from $\mathrm{pH} 5$ to $\mathrm{pH} 9$ by assessing the MIC value and its weightage of SUK 25crude extract. According to Figure 4 (ii) the highest significant activity, $2.44 \pm 0.01 \mu \mathrm{g} / \mathrm{mL}$, against MRSA ATCC 43300 was from Thronton media formulated at initial $\mathrm{pH} 7(\mathrm{P}<0.05)$. Independent $\mathrm{t}$ test revealed a significant difference between the MIC value of $\mathrm{pH} 7$ media and that of $\mathrm{pH} 6$ media, $7.83 \pm 0.01$ $\mu \mathrm{g} / \mathrm{mL}(\mathrm{P}<0.05)$. However, weightage of SUK 25 crude extract produced by $\mathrm{pH} 7$ media was the second highest compared to the rest of the media tested with 1.97 $\pm 0.01 \mathrm{mg}$. Therefore, optimum $\mathrm{pH}$ for SUK25incubation condition of the secondary metabolites was $\mathrm{pH} 7$ Thronton's media for 7 days at $140 \mathrm{rpm}$ (Figure 4). In addition, the inhibitory activity of the extract against MRSA ATCC 43300 showed significant difference between the observed data when the aeration rate was adjusted between 120 to $180 \mathrm{rpm},(\mathrm{P}<0.05)$. However, the aeration rate at $160 \mathrm{rpm}$ and $180 \mathrm{rpm}$ showed insignificant differences $(\mathrm{P}>0.05)$ when MIC value obtained at $3.91 \pm 0.0010 \mu \mathrm{g} / \mathrm{mL}$ and $3.91 \pm 0.0014 \mu \mathrm{g} / \mathrm{mL}$, respectively.

The lowest significant MIC value, $0.975 \pm 0.001 \mu \mathrm{g} / \mathrm{mL}$, was obtained when the aeration rate was at $140 \mathrm{rpm}$, compared to other resorts (P value $<0.05$ ). There were significantly different data regarding the weightage of SUK 25 crude extract when the aeration rate was adjust- ed between 120 to $180 \mathrm{rpm}$, (P value < 0.05). The highest weightage value was observed when the aeration rate was fixed on $160 \mathrm{rpm}$ (P value < 0.05), compared to other aeration rates. However, there was an insignificant value of weightage obtained between $120 \mathrm{rpm}$ and $180 \mathrm{rpm}$, also between $120 \mathrm{rpm}$ and $140 \mathrm{rpm}$ (P value $>0.013)$. Chang liver cells were used to evaluate the cytotoxic activities of SUK 25 extracts. The tested SUK 25 extracts showed no toxicity towards mammalian Chang liver cells with $\mathrm{IC}_{50}$ values of $43.31 \pm 1.24 \mu \mathrm{g} / \mathrm{mL}$. It was categorized as nontoxic as recommended by NCI (National Cancer Institute) which $\mathrm{IC}_{50}$ of crude extract over $30 \mu \mathrm{g} / \mathrm{mL}$ was defined as no cytotoxic.

Figure 1. (i) Comparison between pour plate method (PPM) and spread plate method (SPM) in culturing bacteria for disc diffusion assay. Crude extracts of SUK 25 and MRSA 43300 were used in the tests. (ii) Inhibitory activity of the selected crude SUK $(2 \mathrm{mg} / \mathrm{mL})$ against 3 ATCC strains of MRSA.

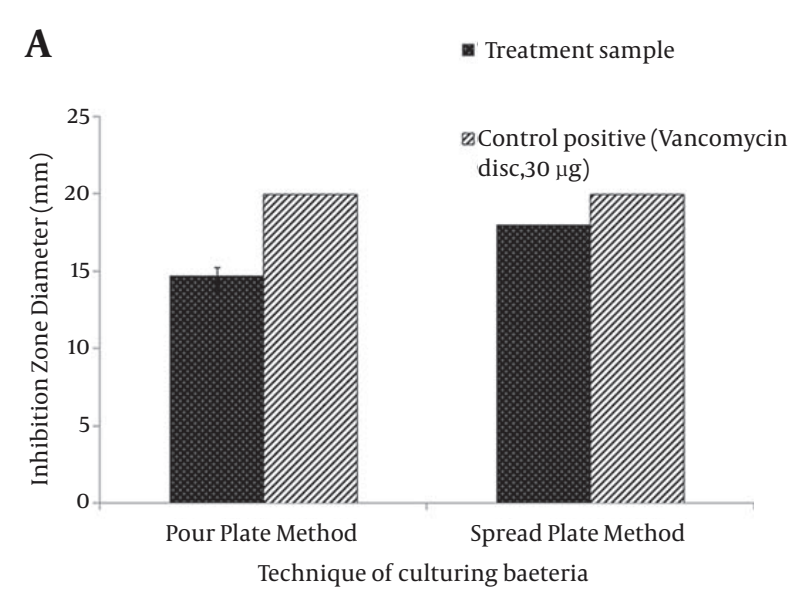

B

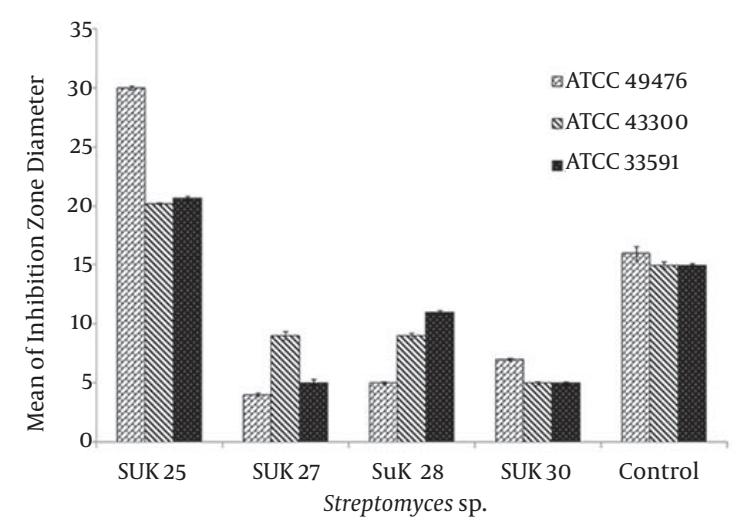

Note: The bar in both graphs (i) showed standard error of the collected data. Vancomycin (30 $\mu \mathrm{g} /$ disc) was used as the positive control (ii). 
Figure 2. Production of SUK 25 Crude Extract (Secondary y-axis in $\mathrm{mg}$ ) from 8 Types of Media and its Effects on inhibition of MRSA ATCC 43300, Presented as MIC Value (Primary y-axis)

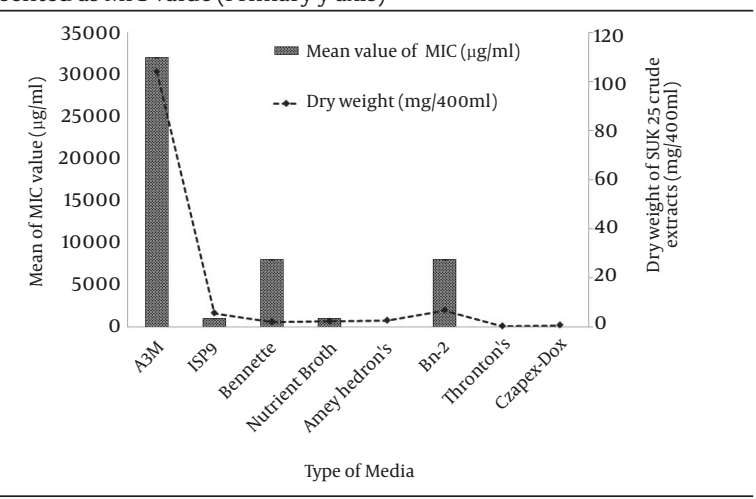

Note: for all samples pH media, fermentation period, and the volume of media were $\mathrm{pH}$ 7, 7 days and $400 \mathrm{~mL}$ respectively.

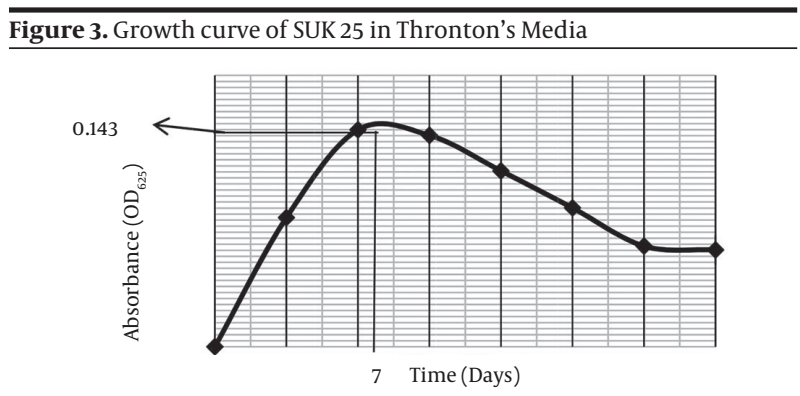

Absorbance reading, A625 taken every 3 days interval was plotted at y-axis. Reading for the 7 -day culture of SUK 25 was 0.143 , showing SUK 25's secondary metabolites harvest at stationary phase of SUK 25 growth.

Figure 4. Anti-MRSA Activity (MIC value) of SUK 25 Crude Extracts against MRSA ATCC $43300\left(1^{\circ}\right.$ y-axis) and Crude Extract (mg) Obtained From 400 mL Thronton's Broth ( $2^{\circ} \mathrm{y}$-axis)
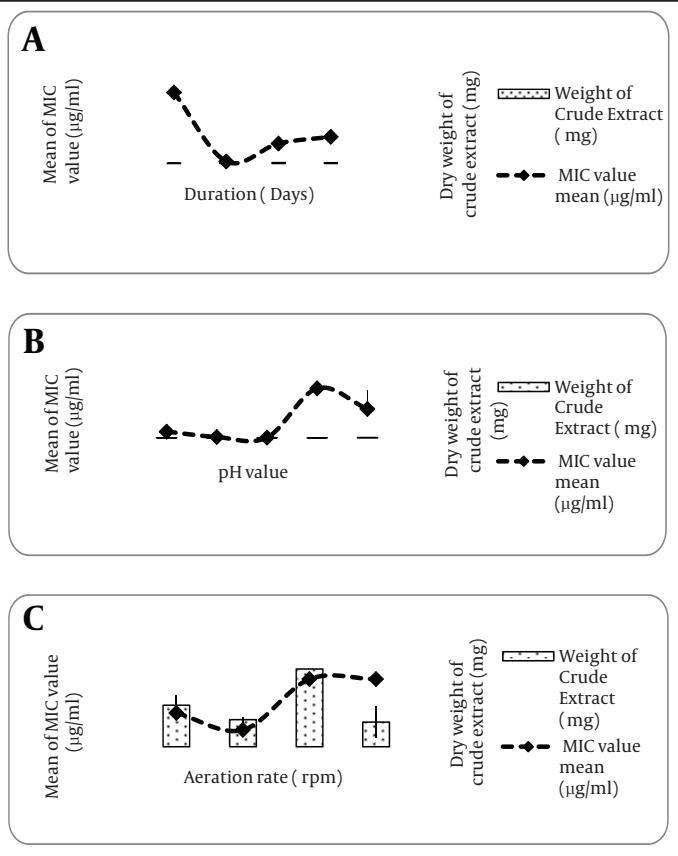

Note, Both parameters were measured up to 21days (i), aeration rate scale ranging from 160-180 rpm within 7 days (ii), and $\mathrm{pH}$ value of media was analyzed from pH 5-pH 7,(iii).

\section{Discussion}

Antibacterial testing of the four Streptomyces sp. SUK isolates was determined to compare the effectiveness of bacterial extract against MRSA. The activity was compared with vancomycin as a control antibiotic. The inhibition of MRSA was assumed to be due to active metabolite action of Actinobacteria. Ghadin et al. (7) reported the inhibition zone produced by the actinobacteria isolate in antibacterial screening assay had the potential medicinal value as an antibacterial agent. In the SPM technique, MRSA cells were spread on the surface of MHA. With PPM technique, the MRSA cells were cultured within MHA. The depth of agar was constant in both techniques, $5 \mathrm{~mm}$. Therefore, SUK 25 extracts (in PPM technique) were potent to penetrate the target cells in the agar incapable. Besides, the secondary metabolites of SUK 25 were extracted using the same ethyl acetate. Hence, SPM technique was much more effective than PPM since the nonpolar compounds in the extracts acted as an anti-MRSA agent compared to polar compounds. In addition, Valli et al. (17) proved that antibacterial screening of Streptomyces sp. crude extracts were practically applied. Moreover, SPM was the standard method in antimicrobial assays applying Kirby- Bauer method (10) and designed for single antimicrobial testing.

High catabolism rate of Streptomycetes cells inhibited the production of bioactive compounds as antimicrobial agents (18). Carbon sources in the media were used for bacteria growth and as a source of energy in microorganism of catabolic process. Comparison of carbon sources of the media showed (Table 1) that only the Nutrient media had no carbon source, whereas $\mathrm{A}_{3} \mathrm{M}$ media with the highest carbon source contained eight different sources as listed in Table 1. The second highest was Bn-2 media with 2 sources and the other media had one source. Other studies $(19,20)$ reported that Streptomycetes used glucose as a carbon source in their growth. Streptomyces coelicolor produced actinordin more effectively when glucose was added into the fermentation media (20). The best media that produced effective anti-MRSA activities from SUK 25 was Thronton media (MIC $=2.44 \mu \mathrm{g} / \mathrm{mL}$ in Figure 4) with crude extracts weight of $0.5 \mathrm{mg}$. Table 1 showed that the only carbon source in Thronton media was mannitol. However, carbon utilization test results (data not shown) on ISP 9 standard media showed that SUK 25 did not use mannitol as a carbon source. Hence, the energy was obtained from nitrogen source such as asparagine $\left(\mathrm{C}_{4} \mathrm{H}_{7} \mathrm{NO}_{4}\right)$, an amino acid.

Borodina et al. (21) reported that asparagines was used as carbon and nitrogen source in S. coelicolor A3 (16) growth. Whereas, Aharonowitz and Demain 1978 (22) found that absence of glycerol in the fermentation media of $S$. clavuligerus causes asparagines acts as carbon and nitrogen sources for Cephalosporin production. Although Czapek-Dox media had a carbon source, it was not used by SUK 25 as a carbon source. Instead, sodium nitrate was used as the energy source. The MIC value obtained from 
the extracts produced in this media was slightly higher than those of the extracts exploited by Thronton media, $(5.86 \mu \mathrm{g} / \mathrm{mL})$. Voelker and Altabe, 2001 (23) reported that nitrate compound metabolisms were converted to ammonium, then to glutamine, an amino acid, amino sugar, nucleotide and other secondary metabolites. Sarigullu et al. stated that antibiotic production by Streptomyces sp. changed by formulation of carbon and nitrogen sources in different media (24). In some circumstances, an enzyme secreted in catabolic process may repress the secretion of secondary metabolite. Different types of carbon sources in $\mathrm{A}_{3} \mathrm{M}$ and Bn-2 media inhibit SUK 25 growth. Therefore, long incubation period is needed to reach the stationary phase and produce active secondary metabolites.

Martin et al. 1999 (25) stated that Carbon Catabolite Repression (CCR) occurs when a variety of carbon sources present in the fermentation medium cause inhibition of penicillin produced by Penicillium chrysogenum. In CCR condition, synthesis of enzymes utilizing other substrates was repressed until the primary substrate was exhausted. For example, production of Gentamycin by Micromonospora purpurea was interfered by the presence of glucose and xylose but not by fructose and maltose (26). An assimilation of nitrogen sources was used to synthesize the cellular components such as protein, nucleic acid, cell wall, primer, and secondary metabolite. Comparison of nitrogen sources for the fermentation media, as stated in Table 1, showed that Bennette, Bn-2 and $A_{3} M$ media had three different nitrogen sources. While Bennette and Bn-2 had similar nitrogen sources, namely yeast extract, meat extracts and $\mathrm{N}-\mathrm{Z}$ case, $\mathrm{A}_{3} \mathrm{M}$ media had protein with 18 types of amino acid and soluble nitrogen amino. Thronton, Nutrient and Arney Hedron media had 2 nitrogen sources (Table 1 ).

Fermentation media which had limited nitrogen sources were inhibited in the growth process, thus the secondary metabolite production was repressed such conditions in Czapek-dox and ISP 9 media. However, the MIC value obtained from Czapek-dox media $(5.86 \mu \mathrm{g} / \mathrm{mL})$ was lower than that of ISP 9 media $(1000 \mu \mathrm{g} / \mathrm{mL})$. Voelker and Altabe, 2001 (23) stated that antibiotic production occurs when nitrogen sources are limited. According to Barios Gonzalez et al. (27) there were four categories of secondary metabolites. The categories included metabolite from aromatic amino acid syntheses such as cancidin, a metabolite produced from amino acids such as Cephalosporins, metabolite from the metabolisms of acetyl-coA (in Kreb Cycle) such as Erythromycin, and metabolite produced by sugars such as streptomycin. Besides, stationary phase of SUK 25 occurs much faster in Czapek-dox media as a contributing factor in the secondary metabolite production. This is because SUK 25 does not use complex carbon sources such as glucose in ISP 9 media. The MIC value of Arney Hedron's media $(6.25 \mu \mathrm{g} / \mathrm{mL})$ was also much lower compared to that of Nutrient media $(1000 \mu \mathrm{g} / \mathrm{mL})$. Both sources of nitrogen in the Nutrient media had organic sources, while Arney Hedron's media nitrogen sources were formulated synthetically.

A non-organic source of nitrogen such as ammonium sulfate makes the $\mathrm{pH}$ media too acidic due to free acid release of fast ammonia metabolism occurance (28). The best media, Thronton, had asparagine and potassium nitrate. According to El-Tayeb et al. (29) potassium nitrate was used to produce Rifamycin B by Amycolatopsis mediterranei. This fact was supported by Voelker and Altabe, 2001 (23), nitrate compound reduced to ammonium and nitrogen metabolism for amino acid synthesis and secondary metabolite. In addition, the asparagine was used to supply energy in the catabolic process. However, limitation of the current study was the variety of phosphate and nitrogen content in every medium, not discussed further in other studies. Furthermore, since SUK 25 required longer period to mature, the optimization process prolonged. This secondary metabolite production of SUK 25 occurs during stationary phase (Figure 3 ) in response to defense mechanism of survival and the protection of the produced spores (30).

Kampen, 1997 (28) stated that the appropriate $\mathrm{pH}$ level acts as buffer to any change of hydrogen ion concentration $(\mathrm{pH})$ when acid and alkaline are formed in fermentation media. Streptomyces sp. growing better in the $\mathrm{pH}$ range of, between pH 7.0-pH7.4 (9). Since the activity of anti-MRSA effects reflected optimum secondary metabolite production, the aeration rate of $140 \mathrm{rpm}$ was selected. aeration supplies the cultured organism with the oxygen (31) and the relationship between aeration rate and oxygen supplied is linear. However, an appropriate oxygen supply resulted in positive effect on growth of cells. As reported by Martins et al. (11), production of secondary metabolite from $S$. olindensis producing Retamycin could not be affected by a high rate of aeration, but a sufficient oxygen supply at $140 \mathrm{rpm}$ increased the production. In the current study, SUK 25 showed significant inhibitory activity, with MIC value of $1.95 \mu \mathrm{g} / \mathrm{mL}$, at aeration of 140 rpm, but not at higher speeds.

The crude extract exploited by Thronton media was categorized as nontoxic by NCI (National Cancer Institute) which defined $\mathrm{IC}_{50}$ of crude extract over $30 \mu \mathrm{g} / \mathrm{mL}$ as noncytotoxic $(14,32)$. The tested SUK 25 extracts were nontoxic against mammalian Chang liver cells with $\mathrm{IC}_{50}$ values of $43.31 \pm 1.24 \mu \mathrm{g} / \mathrm{mL}$. In addition, Malebo et al. (33) reproted that the range of toxicity was divided into four stages according to extracts concentration from highly toxic to non-toxic to human cells. Concentration of extracts less than $1 \mu \mathrm{g} / \mathrm{mL}$ was categorized as highly toxic to human cells. The concentrations between $1 \mu \mathrm{g} / \mathrm{mL}$ to $10 \mu \mathrm{g} /$ $\mathrm{mL}$ of the extracts were categorized as moderately toxic. Next, mild toxic class had fallen into the range between $10 \mu \mathrm{g} / \mathrm{mL}$ to $30 \mu \mathrm{g} / \mathrm{mL}$. Lastly, nontoxic extract concentration was classified as more than $30 \mu \mathrm{g} / \mathrm{mL}$. Therefore, it is important to further investigate this crude extract for cytotoxicity test against cancer cells, to develop bioactive compounds from the nature. According to the results of 
Siti Junaidah A et al.

the current study, SUK 25 was a potential source of antiMRSA agent from Streptomyces sp. and optimum culture conditions for anti-MRSA activities from SUK 25 extracts obtained in Thronton media with initial $\mathrm{pH}$ was $\mathrm{pH} 7$ and aerated at $140 \mathrm{rpm}$. Hence, the SUK 25 crude extracts have a huge potential to be explored as anti-MRSA agents for future drug development.

\section{Acknowledgements}

The authors appreciate the financial support from the Ministry of Higher Education of Malaysia under the grant no. UKM-NN-03-FRGS0042-2009 and Universiti Sultan Zainal Abidin (UniSZA).

\section{Authors' Contributions}

AP Dr Zin N. M and Junaidah S. Ahmad developed the study concept and design. While, interpreting data, statistical analysis and manuscript draft were performed by Junaidah S. Ahmad and Sudi S. Critical revision of the manuscript for important intellectual content were done by AP Dr Zin N. M, AP Dr Basr D. F. and AP Dr Sidek M. H

\section{Funding/Support}

This study had received financial grant from Ministry of Higher Education of Malaysia under the grant no. UKMNN-03-FRGS0042-2009.

\section{References}

1. Sessitsch A, Reiter B, Pfeifer U, Wilhelm E. Cultivation-independent population analysis of bacterial endophytes in three potato varieties based on eubacterial and Actinomycetes-specific PCR of 16S rRNA genes. FEMS Microbiol Ecol. 2002;39(1):23-32.

2. Strobel GA. Microbial gifts from rain forests1. Can J Plant Pathol. 2012;24(1):14-20.

3. Zin NM, Sarmin NI, Ghadin N, Basri DF, Sidik NM, Hess WM, et al. Bioactive endophytic streptomycetes from the Malay Peninsula. FEMS Microbiol Lett. 2007;274(1):83-8.

4. Kannan RR, Iniyan AM, Prakash VS. Isolation of a small molecule with anti-MRSA activity from a mangrove symbiont Streptomyces sp. PVRK-1 and its biomedical studies in Zebrafish embryos. Asian Pac J Trop Biomed. 2011;1(5):341-7.

5. Schrempf H. The Prokaryotes: a handbook on the biology of bacteria. 2006. p. 605-622.The Family Streptomycetaceae, Part II: Molecular Biology.

6. Hickey RJ, Tresner HD. A cobalt-containing medium for sporulation of Streptomyces species. J Bacteriol.1952;64(6):891-2.

7. Ghadin N, Zin NM, Sabaratnam V, Badya N, Basri DF, Lian HH, et al. Isolation and characterization of a novel endophytic Streptomyces SUK 06 with antimicrobial activity from Malaysian plant. Asian J Plant Sci. 2008;2:189-914.

8. Zin NM, Loi CS, Sarmin NM, Rosli AN. Cultivation-Dependent Characterization of Endophytic Actinomycetes. Res J Microbiol. 2010;5(8):717-24.

9. Shirling EB, Gottlieb D. Methods for characterization of Streptomyces species. Int J Syst Bacteriol. 1966;16(3):313-40.

10. Clinical and Laboratory Standards Institute.. Methods for Dilution Antimicrobial Susceptibility Tests for Bacteria That Grow Aerobically Approved Standard-Eighth Edition.Wayne, Pennsylvania, USA: CLSI; 2009.

11. Martins RA, Guimarães LM, Pamboukian CR, Tonso A, Facciotti MCR, Schmidell W. The effect of dissolved oxygen concentration control on cell growth and antibiotic retamycin production in Streptomyces olindensis So20 fermentations. Braz J Chem Eng.
2004;21(2):185-92.

12. Pridham TG, Gottlieb D. The Utilization of Carbon Compounds by Some Actinomycetales as an Aid for Species Determination. $J$ Bacteriol.1948;56(1):107-14.

13. Saha MR, Ripa FA, Islam MZ, Khondkar P. Optimization of Conditions and in Vitro Antibacterial Activity of Secondary Metabolite Isolated from Streptomyces sp. MNK7 J Appl Sci Res. 2010;5:453-9.

14. Thakur D, Bora TC, Bordoloi GN, Mazumdar S. Influence of nutrition and culturing conditions for optimum growth and antimicrobial metabolite production by Streptomyces sp. 201. J Med Mycol. 2009;19(3):161-7.

15. Heydorn A, Suhr-Jessen T, Nielsen J. Growth and production kinetics of a teicoplanin producing strain of Actinoplanes teichomyceticus. J Antibiot (Tokyo). 1999;52(1):40-4.

16. Babu PA, Narasu ML, Kolli S. Discovery of novel anti-proliferative compounds against A549 cells by virtual screening. Chem Bio Inf J. 2010;10(1).

17. Valli S, Suvathi SS, Aysha OS, Nirmala P, Vinoth KP, Reena A. Antimicrobial potential of Actinomycetes species isolated from marine environment. Asian Pac JTrop Biomed. 2012;2(6):469-73.

18. Gallo M, Katz E. Regulation of secondary metabolite biosynthesis: catabolite repression of phenoxazinone synthase and actinomycin formation by glucose. J Bacteriol. 1972;109(2):659-67.

19. Butler MJ, Bruheim P, Jovetic S, Marinelli F, Postma PW, Bibb MJ. Engineering of primary carbon metabolism for improved antibiotic production in Streptomyces lividans. Appl Environ Microbiol. 2002;68(10):4731-9.

20. Ryu YG, Butler MJ, Chater KF, Lee KJ. Engineering of primary carbohydrate metabolism for increased production of actinorhodin in Streptomyces coelicolor. Appl Environ Microbiol. 2006;72(11):7132-9.

21. Borodina I, Krabben P, Nielsen J. Genome-scale analysis of Streptomyces coelicolor A3(2) metabolism. Genome Res. 2005;15(6):820-9.

22. Aharonowitz Y, Demain AL. Carbon catabolite regulation of cephalosporin production in Streptomyces clavuligerus. Antimicrob Agents Chemother.1978;14(2):159-64.

23. Voelker F, Altaba S. Nitrogen source governs the patterns of growth and pristinamycin production in 'Streptomyces pristinaespiralis'. Microbiology. 2001;147(Pt 9):2447-59.

24. Sarigullu FE, Karadeniz E, Untac I, Colak O. Determination of antibacterial activities of isolated Streptomyces strains from soil at Çukurova University in Turkey. J Food Agric Environ. 2013;11(2):9224.

25. Martin JF, Casqueiro J, Kosalkova K, Marcos AT, Gutierrez S. Penicillin and cephalosporin biosynthesis: mechanism of carbon catabolite regulation of penicillin production. Antonie Van Leeuwenhoek. 1999;75(1-2):21-31.

26. Escalante L, Gonzalez R, Obregon AM, Sanchez S. Carbon catabolite regulation of gentamicin formation. J Antibiot (Tokyo). 1992;45(4):465-9.

27. Barrios Gonzalez J, Fernandez FJ, Tomasini A. Microbial secondary metabolites production and strain improvement. Indian JBiotechnol. 2003;2(3):322-33.

28. Kampen WH. Nutritional requirements in fermentation process. In: Vogel HC, Tadaro CL editors. Fermentation and Biochemical Engineering Handbook. Principles, Process Design and Equipment. 2th ed. New Jersey: William Andrew Publishing/Noyes; 1997.

29. El-Tayeb OM, Salama AA, Hussein MMM, El-Sedawy HF. Optimization of industrial production of rifamycin B by Amycolatopsis mediterranei. I. The role of colony morphology and nitrogen sources in productivity. Afr J Biotechnol. 2004;3(5):266-72.

30. Bode HB, Muller R. Analysis of myxobacterial secondary metabolism goes molecular. J Ind Microbiol Biotechnol. 2006;33(7):577-88.

31. Wise WS. The measurement of the aeration of culture media. $J$ Gen Microbiol.1951;5(1):167-77.

32. Hsieh PW, Hsu LC, Lai CH, Wu CC, Hwang TL, Lin YK, et al. Evaluation of the bioactivities of extracts of endophytes isolated from Taiwanese herbal plants. World J Microb Biot. 2009;25(8):1461-9.

33. Malebo HM, Tanja W, Cal M, Swaleh SA, Omolo MO, Hassanali A, et al. Antiplasmodial, anti-trypanosomal, anti-leishmanial and cytotoxicity activity of selected Tanzanian medicinal plants. Tanzan J Health Res. 2009;11(4):226-34. 